which the administration of his own Department is viewed by his colleagues, but also the impetus which, as a member of the Conseil supérieur de la Recherche Scientifique, he has given to the post-war development of French science. Men of science outside France will remember with gratitude the lead he has taken in organizing international colloquia at the Collège de France on various subjects, especially those relating to the physiology of reproduction.

\section{Dr. H. J. Muller, For.Mem.R.S.}

ANOTHER distinguished man of science who has just been elected a foreign member of the Royal Society is Dr. H. J. Muller. Hermann Joseph Muller was one of the three collaborators of T. H. Morgan whose co-ordinated experiments on Drosophila between 1910 and 1916 established the chromosome theory of heredity. Muller was especially responsible for working out the principles of crossing-over between chromosomes or strings of genes, principles now believed to be universal in sexually reproducing organisms, extending even to bacteria and viruses. In 1927 Muller perfected the measurement of spontaneous mutation which enabled him to prove the effect of temperature. It also enabled him to prove the effect of X-rays. Muller's method first made it possible to show that mutations had been induced, and that those, therefore, which were apparently 'spontaneous' might in fact be regarded as determined. It revolutionized genetic technique by providing an artificial source of variation in any organism where it was needed. It led to the discovery that chromosomes could be broken and recombined, first by ionizing radiations and later by chemical reagents, a discovery equally important in plant breeding and cancer research. This work put the study of genes, chromosomes and evolution on an experimental basis. In all the developments which followed, Muller has taken a leading part. Of the greatest importance have been his examination of the genes as units of physiological action and of X-ray breakage, his analysis of the physiological properties of different classes of mutations, his demonstration of the existence of 'inert' genes, and his physiological interpretation of Fisher's theory of dominance. Muller's discussions of the theory of genetics are no less significant than his experimental work. He first suggested the importance of chromosome balance in sex determination. He first (in 1918) showed how the mutations of Oenothera, on which De Vries's theory of evolution was based, could be regarded as due to Mendelian segregation, an explanation established in the following fifteen years. $\mathrm{He}$ first (in 1921) pointed out the analogy between virus and gene and its practical significance. Briefly, Muller's work and ideas, always in advance of the times, moulded the development of genetics in the critical years between 1916 and 1936, and it was in recognition of this achievement that he was awarded the Nobel Prize for Medicine in 1946.

\section{Directorship of the Meteorological Office : \\ Sir Nelson Johnson, K.C.B.}

The Air Ministry has announced that Sir Nelson Johnson is to retire in the autumn from the post of director of the Meteorological Office. Sir Nelson received his scientific training at the Royal College of Science, London, joined the Meteorological Office in 1919 after war service as a pilot, and formed the new meteorological office at the War Office Chemical Defence Research Establishment at Porton in 1921.
The investigation at Porton of the meteorology of the lower layers of the atmosphere gave full scope to his capacity for experimental research; he devoted himself especially to the vertical gradient of temperature, devised new methods for its measurement, and, in Geophysical Memoirs 46 and 77 of the Meteorological Office and elsewhere, he published work which has become classic in this field. He left the Meteorological Office in 1928 for service in the War Office, and in September 1938, on the retirement of Sir George Simpson, returned to the Meteorological Office as director. The Second World War brought a large expansion in the work and size of the Office and a corresponding increase in the director's responsibilities. In spite of a heavy load of day-today administration, Sir Nelson continued the planning, begun in 1938, of a new research organization for meteorology, and in 1941 the Air Ministry Meteorological Research Committee was set up. After the War he carried out a major reorganization of the Meteorological Office, including the setting-up of the planned research organization. In 1946, at the first post-war international conference on moteorology, he was elected president of the International Meteorological Committee, and in that capacity he presided over the Washington Conference of Directors in 1947, which established the Convention of the World Meteorological Organization; in 1951 he became the first president of the new Organization. Great progress in meteorological organization has been made under Sir Nelson's guidance and his services were recognized by the award of a K.C.B. All who have served under Sir Nelson, either in British meteorology or in the international field, will wish him good health during his retirement for many years to come so that he can actively pursue his many and varied interests.

Prof. O. G. Sutton, C.B.E., F.R.S.

Prof. O. G. Sutron, at present dean and Bashforth professor of mathematical physics in the Royal Military College of Science, Shrivenham, who has been appointed to succeed Sir Nelson Johnson, is an expert of world-wide authority in the dynamics of the lower atmosphere. He graduated in mathematics from the University College of Wales, Aberystwyth, and was a lecturer there before joining in 1928 the staff of the Meteorological Office. $\mathrm{He}$ was posted to Porton in 1929 and soon showed his powers by his work on the mathematical theory of turbulent diffusion in the atmosphere. In 1942 he was appointed superintendent of research in ehemical defence at Porton, and during 1943-45 was superintendent of tank armament research. He went to the Radar Research and Development Establishment in 1945 as chief superintendent and in 1947 was appointed Bashforth professor in the Royal Military College of Science. He was scientific adviser to the Army Council in 1951, and is now chairman of the Atmospheric Pollution Research Committee of the Department of Scientific and Industrial Research, as well as serving on other meteorological committees. Prof. Sutton has written a large number of papers on the structure of the lower atmosphere and turbulent diffusion and their applications to such practical problems as evaporation from free water surfaces and the dispersion of smoke from factory chimneys. His recently published text-book, "Micrometeorology", is an exhaustive survey of knowledge on the atmosphere at breathing level. He was elected to the Royal Society in 1949 and awarded a C.B.E. in 1950 . 